\title{
Hubungan antara Karakteristik Ibu, Kecukupan Asupan Zat Besi, Asam Folat dan Vitamin C dengan Status Anemia pada Ibu Hamil di Kecamatan Jatinangor
}

\author{
Rizki Nadiya Putri ${ }^{1}$, Sefita Aryuti Nirmala ${ }^{2}$, Irna Kurnia Aprillani ${ }^{3}$, Tina Dewi \\ Judistiani ${ }^{4}$, Merry Wijaya ${ }^{5}$ \\ Diploma IV Kebidanan, Fakultas Kedokteran, Universitas Padjadjaran ${ }^{1,2,3,4,5}$ \\ rizkinadiya20@gmail.com ${ }^{1}$
}

\begin{abstract}
Diajukan 16 Maret 2019 Diperbaiki 26 Desember 2019 Diterima 30 Desember 2019 ABSTRAK

Latar Belakang: Anemia adalah suatu kondisi dimana eritrosit atau pembawa oksigen dalam tubuh tidak cukup untuk memenuhi kebutuhan fisiologis. Pada wanita hamil anemia bergantung pada banyak faktor. Misalnya, usia, paritas, sosial ekonomi dan trimester kehamilan. Selain itu ada anemia defisiensi besi dan asam folat yang disebabkan oleh asupan nutrisi yang buruk selama kehamilan serta persediaan yang tidak memadai saat mempersiapkan kehamilan. Riset Kesehatan Dasar (Riskesdas) 2013, prevalensi anemia pada wanita hamil adalah $37,1 \%$.

Tujuan: Mengetahui hubungan antara karakteristik ibu, asupan zat besi, asam folat dan vitamin C dengan status anemia ibu hamil di Kecamatan

Jatinangor.

Metode: Penelitian ini analitik korelatif dengan pendekatan crossectional. Populasi 210 ibu di Kecamatan Jatinangor. Teknik pengambilan sampel accidental sampling dengan sampel 66 ibu hamil. Pengambilan data menggunakan metode food record selama 3 hari.

Hasil: Data dianalisis menggunakan uji koefisien kontingensi menunjukkan tidak ada hubungan antara usia $(\mathrm{p}=0,91)$, paritas $(\mathrm{p}=0,42)$, pendidikan $(\mathrm{p}=0,96)$, status gizi $(0,41)$, zat besi $(0,76)$, asam folat $(0,94)$ dan vitamin $C(0,92)$ dengan status anemia.

Kesimpulan: Tidak ada hubungan antara karakteristik ibu, asupan zat besi, asam folat dan Vitamin C dengan status anemia ibu hamil.
\end{abstract}

Kata Kunci: anemia; asam folat; zat besi; vitamin C; karakteristik ibu

\section{ABSTRACT}

Background: Anemia is a condition where erythrocytes or oxygen carriers in the body are not sufficient to meet physiological needs. In pregnant women anemia depends on many risk factors. For example, maternal age, parity, socio-economic and trimester of pregnancy as risk factors for anemia. In addition there are iron and folic acid deficiency anemia caused by poor nutrition intake during pregnancy as well as inadequate supply of iron and folic acid in the body while preparing for pregnancy. Riset Kesehatan Dasar (Riskesdas) in 2013, the prevalence of anemia in pregnant women was $37.1 \%$.

Objective: To determine the relationship between maternal characteristics, iron intake, folic acid and vitamin $C$ with anemia status of pregnant women in Kecamatan Jatinangor.
Method: This research was an analytic with crosssectional study. Population is 210 pregnant women in Kecamatan Jatinangor. Sampling technique is accidental sampling with samples 66 pregnant women. Measurement of nutrition using the food record method wuthin 3 days.

Results: There was no correlation between age $(p=0.91)$, parity $(p=0.42)$, education ( $p=0.96)$, nutritional status (0.41), iron (0.76), acid folate (0.94) and vitamin $C$ (0.92) with anemia status.

Conclusion: There is no correlation between maternal characteristics, iron intake, folic acid and vitamin $C$ with anemia status in pregnant women in Kecamatan Jatinangor

Keywords: anemia; folic acid; iron; vitamin C; maternal characteristics 


\section{PENDAHULUAN}

Anemia adalah suatu kondisi dimana eritrosit atau pembawa oksigen dalam tubuh tidak cukup untuk memenuhi kebutuhan fisiologis. Di Negara berkembang, anemia selama kehamilan merupakan penyebab kesakitan dan kematian wanita hamil yang berisiko bagi ibu dan janin (Siteti et al., 2014). Selama kehamilan, pertumbuhan janin dan plasenta membutuhkan jumlah yang lebih besar dari sirkulasi darah ibu. Hal tersebut menyebabkan peningkatan kebutuhan nutrisi, terutama zat besi dan asam folat. Anemia selama kehamilan bergantung pada banyak faktor risiko. Misalnya, usia ibu, paritas, status sosial-ekonomi dan trimester kehamilan sebagai faktor risiko anemia (Bereka et al., 2017).

Anemia defisiensi besi dan asam folat disebabkan karena asupan nutrisi yang kurang baik selama kehamilan serta persediaan zat besi dan asam folat yang tidak adekuat dalam tubuh selama mempersiapkan kehamilan. Kekurangan zat besi pada ibu hamil dapat dilihat dari besarnya angka kesakitan dan kematian ibu dan janin serta peningkatan risiko berat bayi lahir rendah (BBLR) (Arisman, 2008). Anemia defisiensi besi apabila disertai dengan kekurangan mikronutrien penting lainnya akan membuat keadaan ibu lebih buruk. Akibat kekurangan zat gizi selama kehamilan anemia juga diperburuk juga dengan meningkatnya kebutuhan gizi terkait pertumbuhan janin dalam kandungan (Astuti et al., 2017).

Defisiensi zat besi ibu menyebabkan asupan zat besi ke janin menurun sehingga dapat menyebabkan persalinan prematur, kecil masa kehamilan dan peningkatan kematian perinatal (Renzo et al., 2015).

Beberapa studi menunjukkan persalinan prematur dan bayi berat lahir rendah meningkat pada wanita dengan anemia. Wanita yang memiliki $\mathrm{Hb}$ antara 8 hingga 9,9 gr/dL mempunya risiko lebih tinggi melahirkan prematur dan BBLR dibandingkan wanita dengan $\mathrm{Hb} 10$ hingga 10,9 gr/dL. (Bencaiova and Breymann, 2014).
Berdasarkan World Health Organization (WHO) pada 2012 angka kejadian anemia pada ibu hamil di dunia adalah $41,8 \%$ sedangkan anemia pada ibu hamil di Asia 48,2\% (Fitriasari, 2016). Hasil Riset Kesehatan Dasar (Riskesdas) tahun 2013, diperoleh prevalensi anemia pada ibu hamil adalah 37,1\% (Kemenkes, 2013). Prevalensi ibu hamil dengan anemia di Provinsi Jawa Barat $51,7 \%$ sedangkan prevalensi anemia ibu hamil di Kabupaten Sumedang pada 2017 yaitu sebesar 8,5\% (Dinkes, 2017).

Hasil penelitian Susanti dkk tahun 2017 di Kecamatan Jatinangor, bahwa dari 105 ibu hamil dengan pemeriksaan Complete Blood Count (CBC) diperoleh 21,9\% ibu mengalami anemia (Susanti et al., 2017). Dalam penelitian tersebut, sampel hanya diperoleh dari ibu hamil di pelayanan primer sehingga tidak semua ibu hamil di Kecamatan Jatinangor diketahui kadar Hb-nya.

\section{METODE}

Penelitian ini merupakan penelitian analitik korelatif dengan desain crossectional untuk mengetahui hubungan antara karakteristik ibu, kecukupan zat besi, asam folat dan vitamin $C$ dengan status anemia pada ibu hamil di Kecamatan Jatinangor tahun 2018. Penelitian ini telah mendapatkan izin dari komite etik Fakultas Kedokteran Universitas Padjadjaran No.702/UN6.KEPEC/2018 tanggal 2 Mei 2018. Tempat penelitian di 12 desa di kecamatan Jatinangor dengan populasi ibu hamil yang berjumlah 210 orang. Teknik pengambilan sampel adalah accidental sampling yaitu pengambilan sampel dilakukan dengan cara mengambil subjek yang kebetulan ada atau tersedia dengan jumlah sampel yang didapatkan yaitu sebanyak 66 sampel. Pengukuran asupan zat gizi dengan metode food record dalam waktu tiga hari, selanjutnya disesuaikan dengan buku foto makanan kemudian dihitung menggunakan aplikasi software NutriSurvey. Kecukupan yang dibuat oleh peneliti berdasarkan Permenkes Nomor 75 Tahun 2013 tentang Angka Kecukupan Gizi 
(AKG) di Indonesia. Pemeriksaan $\mathrm{Hb}$ menggunakan sysmex-XP, pemeriksaan berat dan tinggi badan dengan timbangan dan alat ukur tinggi badan.

\section{HASIL DAN PEMBAHASAN}

Dalam penelitian ini, ibu hamil yang datang untuk dilakukan screening anemia serta ikut dalam penelitian berjumlah 66 responden. Dari 66 responden 4 hasil pemeriksaan darah responden mengalami lisis serta 5 responden tidak mengisi food record dengan lengkap, sehingga jumlah responden penelitian yang sesuai dengan kriteria inklusi dan eksklusi yaitu sebanyak 57 responden.

Tabel 1 Hubungan Karakteristik Ibu dengan Status Anemia

\begin{tabular}{|c|c|c|c|c|c|c|}
\hline \multirow[t]{2}{*}{ Karakteristik } & \multicolumn{2}{|c|}{ Anemia } & \multicolumn{2}{|c|}{$\begin{array}{c}\text { Tidak } \\
\text { Anemia }\end{array}$} & \multirow{2}{*}{$\begin{array}{c}\text { Koef. } \\
\text { Korelasi } \\
\text { (r) }\end{array}$} & \multirow{2}{*}{$\begin{array}{c}P^{*} \\
\text { value }\end{array}$} \\
\hline & $\mathbf{N}$ & $\%$ & $\mathbf{N}$ & $\%$ & & \\
\hline \multicolumn{7}{|l|}{ Usia } \\
\hline$<20$ tahun & 2 & 11,1 & 3 & 7,7 & & \\
\hline 20-35 tahun & 13 & 72,2 & 29 & 74,4 & 0,0 & 0,91 \\
\hline$>35$ tahun & 3 & 16,7 & 7 & 17,9 & & \\
\hline \multicolumn{7}{|l|}{ Paritas } \\
\hline Nulipara & 8 & 44,4 & 14 & 35,9 & & \\
\hline Primipara & 4 & 22,2 & 11 & 28,2 & 0,2 & 0,42 \\
\hline Multipara & 5 & 27,8 & 14 & 35,9 & & \\
\hline Grandemulti & 1 & 5,6 & 0 & 0 & & \\
\hline \multicolumn{7}{|l|}{ Pendidikan } \\
\hline SD & 3 & 16,7 & 7 & 17,9 & & \\
\hline $\mathrm{SMP}$ & 8 & 44,4 & 15 & 38,5 & 0,0 & 0,96 \\
\hline SMA & 5 & 27,8 & 13 & 33,3 & & \\
\hline $\begin{array}{l}\text { Perguruan } \\
\text { Tinggi }\end{array}$ & 2 & 11,1 & 4 & 10,3 & & \\
\hline \multicolumn{7}{|l|}{ Status Gizi } \\
\hline Sangat Kurus & 1 & 5,6 & 0 & 0 & & \\
\hline Kurus & 3 & 16,7 & 3 & 9,1 & & \\
\hline Normal & 9 & 50 & 17 & 51,5 & 0,2 & 0,41 \\
\hline Gemuk & 2 & 11,1 & 3 & 9,1 & & \\
\hline Obese & 3 & 16,7 & 10 & 30,3 & & \\
\hline
\end{tabular}

Hubungan usia dengan status anemia ibu hamil

Hasil uji statistik menunjukkan bahwa tidak terdapat hubungan antara status anemia ibu hamil dengan usia ibu ( $p$ value $=0,91$ ) dengan koefisien korelasi sangat lemah $(\mathrm{r}=0,0)$. Hasil penelitian ini sejalan dengan penelitian yang dilakukan oleh Purwaningtyas tahun 2017 (Purwaningtyas and Prameswari, 2017).

Terdapat faktor lain yang lebih dominan mempengaruhi anemia salah satunya pemeriksaan kehamilan. Pemeriksaan kehamilan merupakan kegiatan penting yang harus dilakukan oleh ibu hamil selama kehamilannya untuk kehamilan yang sehat. Saat pemeriksaan kehamilan akan dilakukan screening awal kondisi kehamilan berisiko tinggi salah satunya adalah anemia. Dengan demikian anemia dapat ditangani secara dini serta mengurangi komplikasi yang mungkin terjadi. Melalui pemeriksaan kehamilan, ibu akan mendapatkan informasi memalui buku KIA mengenai faktor risiko dan dampak anemia sehingga ibu akan paham dan mampu mengurangi risiko terjadinya anemia (Purwaningtyas and Prameswari, 2017).

\section{Hubungan paritas dengan status anemia ibu hamil}

Berdasarkan tabel 1 didapatkan bahwa tidak terdapat hubungan antara status anemia ibu hamil dengan paritas ( $p$ value $=0,42$ ) dengan kekuatan korelasi sangat lemah $(\mathrm{r}=0,2)$. Tidak terdapatnya hubungan hubungan paritas dengan kejadian dengan ibu hamil dikarenakan sebagian besar ibu hamil dalam penelitian ini dengan paritas tidak berisiko. Hasil studi menunjukkan wanita hamil dengan paritas 3-5 memiliki risiko anemia lebih tinggi dibandingkan wanita dengan paritas kurang dari 3 (Addis Alene and Mohamed Dohe, 2014).

Hasil penelitian ini sejalan dengan penelitian yang dilakukan oleh Purwaningtyas tahun 2017 bahwa tidak terdapat hubungan antara paritas dengan kejadian anemia pada ibu hamil. Hal ini dapat disebabkan selain karena mayoritas ibu hamil dalam penelitian ini merupakan paritas yang tidak berisiko, terdapat faktor faktor lain yaitu asupan zat besi dan asam folat (Purwaningtyas and Prameswari, 2017).

Seorang ibu multipara dan grandemultipara mempunyai risiko mengalami anemia pada kehamilan berikutnya jika tidak memperhatikan kebutuhan nutrisi selama kehamilan dan ibu nulipara berisiko pula karena belum memiliki pengalaman 
sehingga berdampak pada perilaku yang berkaitan dengan asupan nutrisi yaitu asupan zat besi dan asam folat yang adekuat selama mempersiapkan dan selama kehamilan. Namun jika ibu mempunyai asupan gizi yang baik selama kehamilan, maka akan menurunkan risiko terjadinya anemia (Purwaningtyas and Prameswari, 2017).

\section{Hubungan pendidikan dengan status anemia ibu hamil}

Berdasarkan tabel 1 didapatkan bahwa tidak terdapat hubungan antara status anemia ibu hamil dengan pendidikan terakhir ibu $(p$ value $=0,96$ ) dengan koefisien korelasi sangat lemah $(\mathrm{r}=0,0)$. Hasil penelitian ini sejalan dengan penelitian Amallia dkk tahun 2017 yang menjelaskan bahwa tidak terdapat hubungan yang signifikan antara tingkat pendidikan ibu dengan kejadian anemia (Amallia et al., 2017).

Responden yang memiliki tingkat pendidikan tinggi belum tentu memiliki pengetahuan baik yang dapat mempengaruhi perilaku kesehatannya. Secara teori seseorang yang memiliki pengetahuan yang tinggi akan memiliki perilaku kesehatan yang baik, namun pada penelitian ini berdasarkan hasil food record tercatat $93 \%$ asupan zat besi tidak terpenuhi dan $94,7 \%$ asupan asam folat tidak terpenuhi. Hal ini menunjukkan bahwa ibu terdapat faktor lain yang berpengaruh sehingga ibu tidak dapat mencukupi asupan nutrisi. Ibu hamil dengan tingkat pendidikan rendah, kurang memiliki pengetahuan mengenai anemia sehingga memiliki risiko mengalami anemia, namun jika mereka terbiasa mengkonsumsi makanan yang mengandung zat besi akan lebih menurunkan risiko terjadinya anemia (Amallia et al., 2017).

\section{Hubungan status gizi dengan status anemia ibu hamil}

Berdasarkan tabel 1 didapatkan bahwa tidak terdapat hubungan antara status anemia ibu hamil dengan status gizi ibu sebelum hamil ( $p$ value $=0,41)$ dengan kekuatan korelasi lemah
$(0,2)$. Hasil penelitian ini sejalan dengan Fitriasari (2017) bahwa tidak terdapat hubungan antara status anemia ibu hamil dengan status gizi sebelum hamil. Hal ini dikarenakan status gizi bukan merupakan satu-satunya faktor yang dapat mempengaruhi status anemia pada ibu hamil (Fitriasari, 2016).

Indeks massa tubuh (IMT) adalah hasil hitung yang menggambarkan lemak dalam tubuh berdasarkan perbandingan berat badan sebelum hamil dan tinggi badan. IMT prahamil ibu dianggap dapat menunjukan kualitas gizi ibu pada masa sebelum hamil sekaligus menunjukan ketersediaan gizi dalam tubuh sebelum hamil yang akan memberikan dampak pada ibu dan pertumbuhan janin selama dalam kandungan. IMT prahamil digunakan sebagai pedoman status gizi ibu sebelum hamil dan juga menentukan penambahan berat dan secara optimal. Status gizi ibu berhubungan dengan pola makan ibu sehari-hari. Jika IMT prahamil ibu kurang, maka ibu harus meningkatkan pola makan selama kehamilan untuk memperbaiki status gizi selama kehamilan. Ibu hamil yang dapat memperbaiki pola makan selama kehamilan dengan demikian ia mampu memperbaiki gizinya dan dapat mencegah terjadinya anemia. (Ningrum and Cahyaningrum, 2018).

Pada penelitian ini asupan zat besi, asam folat dan vitamin C didapatkan dari food record, sedangkan data responden dalam mengkonsumsi suplemen atau obat tidak dimasukan dalam penelitian ini. Ibu hamil pada penelitian ini seluruhnya mendapatkan suplemen zat besi yang disertai asam folat sehingga kemungkinan ada faktor yang berhubungan dengan suplemen tersebut diperlukan penelitian lebih lanjut. Tingkat kepatuhan mengonsumsi suplemen akan mempengaruhi pemenuhan zat besi dan asam folat.

Berdasarkan penelitian Utomo dkk tahun 2015 bahwa terdapat hubungan antara tingkat kepatuhan minum tablet Fe dengan kejadian anemia pada ibu hamil. Ibu hamil yang tidak patuh mengonsumsi tablet Fe berisiko 3,7 kali 
lebih besar untuk menderita anemia. Hal tersebut dikarenakan konsumsi tablet Fe akan membantu meningkatkan produksi sel darah merah dan $\mathrm{Hb}$ dalam tubuh (Widji Utomo et al., 2016).

Tabel 2 Hubungan Asupan Zat Gizi dengan Status Anemia Ibu Hamil Asupan Nutrisi

\begin{tabular}{|c|c|c|c|c|c|c|}
\hline \multirow{2}{*}{$\begin{array}{l}\text { Asupan } \\
\text { Nutrisi }\end{array}$} & \multicolumn{2}{|c|}{ Anemia } & \multicolumn{2}{|c|}{$\begin{array}{c}\text { Tidak } \\
\text { Anemia }\end{array}$} & \multirow{2}{*}{$\begin{array}{l}\text { Koef. } \\
\text { Korelasi } \\
\text { (r) }\end{array}$} & \multirow{2}{*}{$\begin{array}{c}P \\
\text { value }\end{array}$} \\
\hline & $\mathbf{n}$ & $\%$ & $\mathbf{n}$ & $\%$ & & \\
\hline \multicolumn{7}{|l|}{ Zat Besi } \\
\hline Terpenuhi & 1 & 5,6 & 3 & 7,7 & 0,0 & 0,76 \\
\hline $\begin{array}{l}\text { Tidak } \\
\text { Terpenuhi }\end{array}$ & 17 & 94,4 & 36 & 92,3 & & \\
\hline \multicolumn{7}{|l|}{ Asam Folat } \\
\hline Terpenuhi & 1 & 7,7 & 2 & 5,1 & 0,0 & 0,94 \\
\hline $\begin{array}{l}\text { Tidak } \\
\text { Terpenuhi }\end{array}$ & 17 & 92,3 & 37 & 94,9 & & \\
\hline \multicolumn{7}{|l|}{ Vitamin C } \\
\hline Terpenuhi & 7 & 38,9 & 14 & 35,9 & 0,0 & 0,82 \\
\hline $\begin{array}{l}\text { Tidak } \\
\text { Terpenuhi }\end{array}$ & 11 & 61,1 & 25 & 64,1 & & \\
\hline
\end{tabular}

Berdasarkan tabel 2 hasil analisis statistik dengan uji Koefisien Kontingensi diperoleh asupan zat besi memiliki $p$ value $0,76(>0,05)$ sehingga dapat disimpulkan tidak terdapat hubungan antara asupan zat besi dengan status anemia ibu hamil di Kecamatan Jatinangor. Asupan asam folat memiliki $p$ value $0,94(>0,05)$ sehingga dapat disimpulkan tidak terdapat hubungan antara asupan asam folat dengan status anemia. Asupan vitamin $\mathrm{C}$ memiliki $p$ value $0,82(>0,05)$ sehingga disimpulkan tidak terdapat hubungan antara asupan vitamin $\mathrm{C}$ dengan status anemia ibu hamil.

\section{Hubungan asupan zat besi dengan status anemia ibu hamil}

Berdasarkan tabel 2 didapatkan bahwa tidak terdapat hubungan antara status anemia ibu hamil dengan asupan zat besi selama kehamilan $(p$ value $=0,76)$ dengan kekuatan korelasi sangat lemah $(\mathrm{r}=0,0)$. Hasil penelitian ini sejalan dengan penelitian yang dilakukan oleh Purwaningtyas tahun 2017 bahwa tidak terdapat hubungan antara kecukupan asupan zat besi dengan kejadian anemia pada ibu hamil (Purwaningtyas and Prameswari, 2017).

Tidak terdapatnya hubungan antara kecukupan zat besi dengan status anemia pada ibu hamil dalam penelitian ini dikarenakan ada faktor lain yang berpengaruh terhadap anemia selain asupan zat besi yaitu konsumsi tablet tambah darah. Dalam penelitian ini hanya meneliti mengenai asupan zat besi dalam asupan makanan sehari-hari, sehingga tidak diteliti mengenai pola konsumsi tablet tambah darah ibu. Tablet tambah darah mengandung $60 \mathrm{mg}$ zat besi dan $400 \mathrm{mcg}$ asam folat yang diberikan pada ibu hamil minimal 90 tablet selama kehamilan dan diminum satu kali setiap hari. Pemberian satu tablet tambah darah dapat membantu memenuhi kebutuhan zat besi per hari (Purwaningtyas and Prameswari, 2017).

Zat besi dibutuhkan terutama pada trimester kedua dan ketiga kehamilan. Suplemetasi zat besi dibutuhkan untuk memenuhi kekurangan zat besi selama kehamilan (Susanti et al., 2017).

\section{Hubungan asupan asam folat dengan status anemia ibu hamil}

Berdasarkan hasil penelitian ini didapatkan bahwa tidak terdapat hubungan antara status anemia ibu hamil dengan asupan asam folat selama kehamilan ( $p$ value $=0,94$ ) dengan kekuatan korelasi sangat lemah $(\mathrm{r}=0,0)$. Hasil penelitian ini sejalan dengan penelitian Hasan Syah (2014) bahwa tidak terdapat hubungan antara asupan asam folat dengan status anemia ibu hamil (Syah et al., 2014).

Tidak terdapatnya hubungan antara asupan asam folat dengan status anemia pada ibu hamil dalam penelitian ini dikarenakan mayoritas responden dalam penelitian memiliki asupan asamfolat yang tidak terpenuhi yaitu sebanyak $94,7 \%$.

Asupan asam folat yang tidak terpenuhi selain dipengaruhi oleh pola makan juga dapat dipengaruhi oleh jenis pengolahan makanan. Hasil food record menunjukan sebagian besar responden mengonsumsi makanan sumber zat besi dan asam folat yaitu seperti ikan, daging ayam, ati ampela, sayur bayam, kangkung, tahu dan tempe. Pengolahan makanan sumber zat besi heme responden sebagian besar adalah dengan cara penggorengan. 
Penggunaan panas dalam proses pengolahan makanan dapat berpengaruh terhadap nilai gizi bahan pangan tersebut. Proses penggorengan menggunakan suhu diatas $160^{\circ} \mathrm{C}$ yang dapat merusak kandungan vitamin dan mineral. Pengolahan bahan pangan dengan menggunakan suhu tinggi atau penggorengan dapat menyebabkan terjadinya penguapan air pada bahan pangan tersebut. Asam folat dapat dihancurkan oleh panas dan cepat larut dalam air. Oleh karena itu, kandungan folat akan hilang jika dimasak terlalu lama, menghangatkan makanan terusmenerus dan penyimpanan yang lama (Sundari et al., 2015). Selain itu faktor lain yang mempengaruhi ialah konsumsi tablet tambah darah yang tidak diteliti dalam penelitian ini. Tablet tambah darah mengandung $60 \mathrm{mg}$ zat besi dan $400 \mathrm{mcg}$ asam folat yang diberikan pada ibu hamil minimal 90 tablet selama kehamilan dan diminum satu kali setiap hari. Pemberian satu tablet tambah darah dapat membantu memenuhi kebutuhan asam folat setiap hari (Purwaningtyas and Prameswari, 2017).

Asam folat berperan dalam sintesis DNA dan pertumbuhan sel. Kekurangan asam folat mengakibatkan sintesis DNA tidak sempurna dan sel darah merah tidak dapat matang dengan baik. Akibatnya sel darah merah tidak dapat membawa oksigen untuk kebutuhan tubuh sehingga dapat terjadi anemia (Whitney and Rolfes, 2011).

\section{Hubungan asupan vitamin $\mathrm{C}$ dengan status anemia ibu hamil}

Berdasarkan tabel 2 didapatkan bahwa tidak terdapat hubungan antara status anemia ibu hamil dengan asupan vitamin $C$ selama kehamilan ( $p$ value $=0,82$ ) dengan kekuatan korelasi sangat lemah $(\mathrm{r}=0,0)$. Hasil penelitian ini sejalan dengan penelitian yang dilakukan oleh Purwaningtyas dkk tahun 2017 dimana tidak terdapat hubungan antara asupan vitamin C dengan anemia pada ibu hamil (Purwaningtyas and Prameswari, 2017).

Tidak terdapatnya hubungan antara asupan vitamin dengan status anemia ibu hamil dapat terjadi karena kebiasaan responden mengonsumsi sumber vitamin $\mathrm{C}$ yang tidak dibarengi dengan sumber makanan zat besi sehingga tidak memiliki dampak yang signifikan bagi ketersediaan zat besi dalam tubuh. Sebagian besar responden dalam penelitian ini kurang mengonsumsi makanan dan buah-buahan sebagai sumber utama vitamin $C$ seperti jeruk dan pepaya serta kurangnya menambahkan brokoli dan tomat ke dalam konsumsi sayuran harian.

Vitamin C sangat dibutuhkan tubuh untuk pembentukan sel-sel darah merah. Adanya vitamin C dalam makanan yang dikonsumsi akan memberikan suasana asam sehingga zat besi yang lebih mudah diserap usus halus. Absorpsi zat besi dalam bentuk non heme bila ada vitamin C (Whitney and Rolfes, 2011).

\section{KESIMPULAN}

Tidak terdapat hubungan antara karakteristik ibu, asupan zat besi, asam folat dan vitamin $C$ dengan status anemia pada ibu hamil ibu hamil di Kecamatan Jatinangor.

\section{ACKNOWLEDGEMENT}

Penulis menyampaikan terimakasih kepada seluruh responden, pembimbing, penguji dan semua pihak terkait yang telah membantu dan memberikan bimbingan serta dukungannya

\section{DAFTAR PUSTAKA}

Addis Alene, K. \& Mohamed Dohe, A. 2014. Prevalence of Anemia and Associated Factors among Pregnant Women in an Urban Area of Eastern Ethiopia. Anemia, 2014, 1-7.

Amallia, S., Afriyani, R. \& Utama, S. 2017. Faktor Risiko Kejadian Anemia pada Ibu Hamil di Rumah Sakit BARI Palembang.

Arisman 2008. Gizi dalam Daur Kehidupan 
: Buku Ajar Ilmu Gizi. Jakarta: EGC.

Astuti, S., Susanti, A. I., Nurparidah, R. \& Mandiri, A. 2017. Asuhan Ibu dalam Masa Kehamilan, Jakarta, Erlangga.

Bencaiova, G. \& Breymann, C. 2014. Mild Anemia and Pregnancy Outcome in a Swiss Collective. Journal of Pregnancy, 2014, 1-7.

Bereka, S. G., Gudeta, A. N., Reta, M. A. \& Ayana, L. A. 2017. Prevalence and Associated Risk Factors of Anemia among Pregnant Women in Rural Part of JigJiga City, Eastern Ethiopia: A Cross Sectional Study. Journal of Pregnancy and Child Health, 4.

Dinkes 2017. Profil Dinas Kesehatan

Kabupaten Sumedang 2017. Sumedang.

Fitriasari, I. 2016. Faktor-faktor yang Berhubungan dengan Kejadian Anemia Pada Ibu Hamil Trimester III di Puskesmas Tegalrejo Tahun 2016. Journal Ners And Midwifery Indonesia.

Kemenkes 2013. Riset Kesehatan Dasar 2013. Badan Penelitian dan Pengembangan Kesehatan.

Ningrum, E. \& Cahyaningrum, E. 2018. Status Gizi Pra Hamil Berpengaruh Terhadap Berat dan Panjang Badan Bayi Lahir. Medisains : Jurnal Ilmiah Ilmu-ilmu Kesehatan, 16,89.

Purwaningtyas, M. L. \& Prameswari, G. N. 2017. Higea : Jurnal of Public Health Research and Development. In: ILMU KESEHATAN MASYARAKAT, F. I. K., UNIVERSITAS NEGERI SEMARANG, INDONESIA (ed.). Semarang.

Renzo, G. C. D., Spano, F., Giardina, I., Brillo, E., Clerici, G. \& Roura, L. C. 2015. Iron deficiency anemia in pregnancy. Future Science, 11, 892.

Siteti, M. C., Namasaka, S. D., Ariya, O. P., Injete, S. D. \& Wanyonyi, W. A. 2014. Anaemia in Pregnancy: Prevalence and Possible Risk Factors in Kakamega County, Kenya. Science Journal of Public Health, 2, 216.

Sundari, D., Almasyhuri \& Lamid, A. 2015. Pengaruh Proses Pemasakan Terhadap Komposisi Zat Gizi Bahan Pangan Sumber Protein. Media Litbangkes, 25, 235-242.

Susanti, A. I., Sahiratmadja, E., Winarno, G., Sugianli, A. K., Susanto, H. \& Panigoro, R. 2017. Low Hemoglobin among Pregnant Women in Midwives Practice of Primary Health Care, Jatinangor, Indonesia: Iron Deficiency Anemia or $\beta$-Thalassemia Trait? Anemia, 2017, 1-5.

Syah, M., Thaha, A. \& Kesumasari, C. 2014. Status Zat Gizi Mikro (Besi, Asam Folat dan Seng) dan Kerusakan DNA Pada Anemia Ibu Hamil Di Kecamatan Bontonompo Dan Bontonompo Selatan Kabupaten Gowa. . Fakultas Kesehatan Masyarakat Universitas Hasanuddin, 3, 10-11.

Whitney, E. \& Rolfes, S. R. 2011. Understanding Nutrition, USA, Wadsworth.

Widji Utomo, A. P., Nurdiati, D. S. \& Padmawati, R. S. 2016. Rendahnya asupan zat besi dan kepatuhan mengonsumsi tablet besi berhubungan dengan kejadian anemia pada ibu hamil di Wilayah Kerja Puskesmas I Kembaran, Banyumas. Jurnal Gizi dan Dietetik Indonesia (Indonesian Journal of Nutrition and Dietetics), 3,41. 